\title{
Paweł Kowal \\ Między Majdanem a Smoleńskiem rozm. Piotr Legutko, Dobrosław Rodziewicz Kraków 2012, ss. 293
}

Słowa klucze: Szymon Gajewski, polska polityka zagraniczna, Paweł Kowal, PJN, Polska Jest Najważniejsza, stosunki polsko-ukraińskie, Między Majdanem a Smoleńskiem, Piotr Legutko, Dobrosław Radziewicz

\section{Paweł Kowal - analityk i praktyk o polityce wschodniej}

$\mathbf{P}$ olityka wschodnia jest tematem szeroko poruszanym w polskiej prasie, publicystyce i politycznych debatach. Specyficzne położenie geopolityczne Polski w Europie Środkowo-Wschodniej pomiędzy aspirującymi do roli światowych potęg, Rosją i Niemcami, determinuje prowadzenie takiej polityki, która pozwalałaby Polsce zachować podmiotowość $\mathrm{w}$ relacjach z obydwoma sąsiadami. Jednocześnie nasz kraj pozostaje liderem wśród państw środkowoeuropejskich. $\mathrm{Z}$ jednej strony jest to szansa, by w oparciu o współpracę z nimi budować silną pozycję Polski na arenie międzynarodowej. Z drugiej strony pociąga to za sobą zobowiązanie, by wziąć na siebie ciężar wspierania pozostałych, a nawet rezygnacji $z$ własnych interesów na rzecz dobra całego regionu. To specy- ficzne położenie Polski było zauważane już w przeszłości, dlatego dziś we współczesnej myśli politycznej zaobserwować można różne koncepcje polskiej polityki wschodniej. $\mathrm{Na}$ „rynku idei” istnieją takie pojęcia jak „polityka jagiellońska”, dla której alternatywą miałaby być „polityka piastowska”. Wskazuje się również na dwie różne tradycje: piłsudczykowską i endecką. Silny wpływ na dzisiejsze myślenie o Wschodzie ma również koncepcja stworzona przez Jerzego Giedroycia w środowisku paryskiej „Kultury”.

Głosem w tej dyskusji jest książka Między Majdanem a Smoleńskiem. Właściwie jest to opublikowany w formie książkowej wywiad rzeka przeprowadzony z Pawłem Kowalem przez Piotra Legutkę i Dobrosława Rodziewicza. Zarówno doświadczenie polityczne jak i naukowy dorobek autora wskazują, że jest on osobą niezwykle kompetentną w obszarze polityki wschodniej. 
Prezes partii Polska Jest Najważniejsza w latach 1998-2000 w czasie kadencji premiera Jerzego Buzka, pracował w Kancelarii Prezesa Rady Ministrów, gdzie był naczelnikiem wydziału w Departamencie Spraw Zagranicznych. Do jego kompetencji należały wtedy stosunki z Polonią i Polakami na Wschodzie oraz organizowanie wizyt premiera na Wschodzie. Od lipca 2006 r. do listopada 2007 r. roku pełnił funkcję wiceministra w Ministerstwie Spraw Zagranicznych. W roku 2009 r. uzyskał mandat w Parlamencie Europejskim. Ze względu na swoje szerokie zainteresowania Wschodem wybrany został na przewodniczącego komisji Unia Europejska-Ukraina.

Piastowane przez niego funkcje miały związek z jego zainteresowaniem wschodnimi sąsiadami Polski. Pasja ta przełożyła się na naukowe badania nad skomplikowanymi relacjami pomiędzy Polską a państwami regionu jak również na pogłębioną analizę ich sytuacji wewnętrznej. W latach 1998-1999 Paweł Kowal był dyrektorem programu Państwo Polskie wobec Polaków na Wschodzie. Poszukiwanie modelu polityki w Ośrodku Myśli Politycznej w Krakowie. W Collegium Civitas prowadził zajęcia poświęcone polityce wschodniej. Obecnie jest pracownikiem Instytutu Studiów Politycznych PAN. Przegląd publikacji Pawła Kowala pozwala stwierdzić, że większość z nich dotyczyła kwestii wschodnich. Zresztą recenzowana książka nie jest też pierwszą w jego dorobku. W 2011 r. wydał Krajobrazy z Mistralami $w$ tle, która w całości poświęcona była polskiej polityce wschodniej.

Tak szeroko zaprezentowana sylwetka autora recenzowanej pozycji może wydawać się zbyt szczegółowa. Okazuje się jednak niezbędna, gdyż Czytelnik na jej podstawie może mieć pewne przypuszczenia, czego spodziewać się po lekturze
Między Majdanem a Smoleńskiem. Przede wszystkim oczekiwać może pewnego rodzaju syntezy między akademickimi koncepcjami a polityczną praktyką jak również konfrontacji teoretycznych założeń ze skomplikowaną rzeczywistością międzynarodową. W tym zakresie książka spełnia oczekiwania. Przeważa w niej opis wydarzeń i konkretnych sytuacji, które obrazują polityczne zależności i układy w państwach Europy Wschodniej. Wszystkiemu towarzyszy jednocześnie naukowa analiza, która wyznacza kierunek polskiej polityce wschodniej. Przez pryzmat teorii stosunków międzynarodowych i nauk politycznych Paweł Kowal interpretuje konkretne wydarzenia w państwach na Wschodzie i stara się dobrać takie narzędzia rozwiązania trudnych kwestii, które są wyznaczone przez podstawowy paradygmat działania.

Tytuł książki określa ramy czasowe, a więc znaleźć w niej można przede wszystkim analizę wydarzeń, które miały miejsce pomiędzy „pomarańczową rewolucją" w 2004 r., a katastrofą smoleńską w kwietniu 2010. Przedział ten nie jest sztywny, ważniejsze jest całościowe ujęcie poruszanej problematyki. Dwa rozdziały dotyczą Ukrainy, co ma ukazać zarówno wagę wydarzeń, które się tam rozgrywają, jak i istotne znaczenie tego państwa dla polskiej polityki wschodniej. Po jednym rozdziale natomiast poświęcono Białorusi, Gruzji i Rosji. W książce osobna część została przeznaczona dla polskiej polityki wschodniej - jej ewolucji jak i charakterystyki konkretnych działań w jej ramach podejmowanych. Nie zabrakło również miejsca dla odniesienia się do najtragiczniejszego w powojennej historii Polski wydarzenia, jakim była katastrofa smoleńska.

Koncepcja polskiej polityki wschodniej zaprezentowana przez Pawła Kowala 
mieści się w duchu tradycji II Rzeczpospolitej, realizowanej przez obóz Józefa Piłsudskiego. Politykę tę Paweł Kowal określa terminem prometeizmu, o której mówi w sposób następujący: „Idea przetrwała dziesiątki lat w polskiej myśli politycznej, jej altruistyczny motyw niesienia wolności wbrew ciemiężycielom, a nawet ryzyko zemsty z ich strony - wszystko to odpowiada

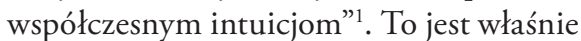
paradygmat, jaki Paweł Kowal przykłada do wszystkich polskich działań na Wschodzie. Nie jest to więc polityka neutralności, ale silnego i stanowczego zaangażowania w Europie Wschodniej i na Kaukazie, nawet jeśli z tego powodu nie do uniknięcia staje się w konflikt z Rosją, która również $\mathrm{w}$ tym regionie posiada swoje strategiczne cele. Dla Kowala „prometejska” koncepcja polityki zagranicznej wyznacza polski stosunek do słabszych państw regionu, dla których pomoc nie jest motywowana tylko polskim interesem, Jednocześnie wyznacza ona stosunek do Federacji Rosyjskiej, wobec której zajmować trzeba stanowisko autonomiczne $\mathrm{z}$ katalogiem jasno sprecyzowanych interesów własnych. Nie oznacza to jednak zaniechania budowy próby relacji dwustronnych. Jednak musi się to zawsze odbywać w oparciu o pełny realizm tego, czego można spodziewać się po wschodnim partnerze.

To co niewątpliwie wyróżnia książkę Pawła Kowala od pozostałych o podobnej tematyce jest bezpośrednie uczestnictwo jej autora w kreowaniu polskiej polityki wschodniej. Autor Między Majdanem a Smoleńskiem umieszcza wiele relacji z wydarzeń, w których sam brał udział. Praca w MSZ, a w końcu doświadczenie

1 P. Kowal, Między Majdanem a Smoleńskiem, rozm. Piotr Legutko, Dobrosław Rodziewicz, Kraków 2012, s. 153-154. z Parlamentu Europejskiego powoduje, że książka ta ma walor opisu praktycznej polityki. Taki wyjątkowy charakter mają chociażby dwa zdarzenia: jako jeden z nielicznych przedstawicieli Unii Europejskiej, Paweł Kowal spotkał się w więzieniu z byłą premier Ukrainy Julią Tymoszenko, a będąc najbliższym współpracownikiem Jarosława Kaczyńskiego znalazł się razem z nim w Smoleńsku w parę godzin po katastrofie. Oba wydarzenia wskazują jak wielkim autorytetem cieszył się zarówno w strukturach europejskich w ramach relacji z parterem ukraińskim jak i w jednym z politycznych obozów w Polsce.

Bardzo dobra znajomość Wschodu, nie tylko z naukowych książek, ale szerokich kontaktów z wieloma osobistościami państw regionu, rzutuje również na przedstawiane przez autora analizy. Nie są one oderwane od kontekstu, wręcz przeciwnie, silnie są w nim osadzone. Dlatego też wiele sądów Pawła Kowala wymyka się spoza przyjętych w Polsce stereotypów. W potocznym przekonaniu na Ukrainie „pomarańczowi” są proeuropejscy, a „niebiescy” prorosyjscy. Autor rozprawia się z tym sądem pokazując wielowątkowość problemu, podobnie czyniąc z opiniami na temat Polaków-rusofobów czy też prezydenta Białorusi chronionego przez rosyjskie interesy. W tym ostatnim przypadku Paweł Kowal ujawnia ciekawy scenariusz, który wskazuje na to, że zakończenie dyktatury Łukaszenki może być w pewnym momencie inspirowane właśnie z kręgów Kremla.

Między Majdanem a Smoleńskiem prezentuje również bardzo cenną analizę polskiej polityki wschodniej. Określoną wartością jest to, że Paweł Kowal w momencie powstawania tej książki funkcjonował poza sporami politycznymi dwóch największych partii - Platformy Obywatelskiej i Prawa i Sprawiedliwości. Takie spoj- 
rzenie z zewnątrz umożliwiło zachowanie określonego dystansu. Autor docenia politykę prezydenta Lecha Kaczyńskiego, wskazuje na jej przemyślany charakter i odważne założenia. Przede wszystkim podkreśla rolę prezydenta w czasie agresji rosyjskiej na Gruzję w 2008 r., oraz zaangażowanie na rzecz wspólnego, regionalnego bezpieczeństwa energetycznego, jakim miał być rurociąg Odessa-BrodyGdańsk. Można powiedzieć, że książka ta w jakimś zakresie stara się oddać sprawiedliwość prezydentowi, którego polityka była nieustępliwie krytykowana i przedstawiana w jednoznacznie negatywnym świetle. Nie oznacza to jednak, że zgodnie z przyjętą dziś logiką myślenia, Paweł Kowal przeprowadza całkowitą krytykę obozu rządzącego z premierem Donaldem Tuskiem na czele. Co prawda wskazuje na wiele błędów w prowadzonej przez ówczesne władze polityki wschodniej, jednocześnie potrafi wskazać na pozytywne zmiany, które w niej zachodzą.

Według Kowala zagrożeniem dla polskiej polityki wschodniej staje się pasywność. Członkostwo w Unii Europejskiej, które daje Polsce narzędzia do bardziej aktywnej polityki w regionie niesie ze sobą niebezpieczeństwo pozostawienia instytucjom unijnym kompetencji w tym zakresie. Paweł Kowal, jako przykład podaje negocjacje nad nową umową gazową pomiędzy Rosją i Polską. Niekorzystne dla naszego państwa warunki porozumienia zostały zablokowane przez Brukselę. Patrząc całościowo na polską aktywność na Wschodzie, Kowal bardzo ubolewa nad brakiem kontynuacji działań prowadzonych przez poprzedników i uzależnianie polityki zagranicznej od wewnętrznych, partyjnych sporów. Czyni tom, jak uważa, z Polaków niewiarygodnych partnerów i uniemożliwia prowadzenie konsekwent- nej polityki wschodniej i realizowanie przedsięwzięć w wieloletniej perspektywie.

Oprócz zalet wskazanych powyżej książka Pawła Kowala posiada jedną, jak się wydaje, poważną słabość. Otóż autor Między Majdanem a Smoleńskiem całą swoją analizę podporządkowuje założeniu koniecznej integracji państw Europy Wschodniej ze strukturami Unii Europejskiej. Czytelnik może odnieść wrażenie, że staje się to niejako „dogmatem” autora książki. Polska została zresztą przedstawiona jako państwo, które do roku 2004, a więc jej wejścia do UE, w zasadzie nie prowadziła realnej polityki wschodniej. Dopiero członkostwo w strukturach europejskich dało ku temu praktyczne narzędzia. Innymi słowy, bez politycznego bytu, jakimi jest zjednoczona Europa, w zasadzie niemożliwe jest prowadzenie skutecznej polskiej polityki wschodniej. Alternatywa dla państw regionu prezentuje się natomiast w sposób następujący: albo Rosja, albo Unia Europejska. Zadaniem Polski jest wykorzystywanie na Wschodzie możliwości, które daje członkostwo w UE i czynienie wszystkiego by europejskie państwa na wschód od naszej granicy w przyszłości stały się również jej częścią.

Po pierwsze, należy poddać w wątpliwość słuszność tylko jednej drogi. Czy autor, który stara się niuansować i łamać schematy myślenia na innych polach może tak bezkrytycznie przyjmować bezalternatywność jakiegoś rozwiązania? Po drugie, co zdaje się być nawet ważniejsze, Unia Europejska znajduje się obecnie w najpoważniejszym kryzysie od czasów jej powstania. Jest to kryzys zarówno ekonomiczny jak i polityczny. W książce trudna sytuacja Unii pojawia się raz i w żaden sposób nie zostaje odniesiona do polityki wschodniej. Skoro Paweł Kowal stawia tak poważną tezę, że punktem odniesienia dla polityki 
wschodniej musi być Europa Zachodnia, to wątku tego nie można pominąć. $Z$ jednej strony powinna pojawić się w Polsce nowa koncepcja polityki wschodniej, która uwzględniałaby najgorsze scenariusze dla Unii i konieczność prowadzenia polityki wysoce autonomicznej bez opierania się na narzędziach unijnych. Z drugiej strony państwa Europy Wschodniej, które wciąż traktują Unię, jako miejsce dobrobytu i politycznej stabilizacji, dla których integracja z nią może być bardziej „kuszącą” propozycją niż uzależnienie od Rosji, widząc pogłębiający się kryzys unijny i mniejszą wolę do otwarcia na nowych członków, mogą zweryfikować swoją prozachodnią orientację. Wobec tego Polska również nie może pozostać „bezbronna”. Powinna istnieć koncepcja, która stanowiłaby alternatywę dla słabnącej UE. Takich i podobnych refleksji nie można znaleźć w Między Majdanem a Smoleńskiem, jak gdyby Unia była wciąż w sytuacji sprzed kryzysu w roku 2009. Wydaje się, że zagadnieniu temu powinien poświęcony być cały, osobny rozdział, który uwzględniałby dzisiejszą sytuację zachodniej Europy.
Książka Pawła Kowala jest niewątpliwie książką godną polecenia i ważnym głosem w dyskusji na temat polityki wschodniej. Trudno zresztą pominąć zdanie kogoś, kto większość swojego życia naukowego i politycznego poświęcił temu zagadnieniu. Walorem Między Majdanem a Smoleńskiem jest przede wszystkim bogate doświadczenie autora, wielka znajomość realiów panujących na Wschodzie i teoretyczna synteza, która powoduje, że książka nie staje się przytłaczającą sumą wielu faktów bez żadnych powiązań i bez recept zaradzenia trudnościom. Co prawda mimo jego zapewnień, że tak nie jest, momentami można odnieść wrażenie, że autor prezentuje przesadny optymizm. Zawsze zauważa bowiem jakieś możliwości rozwiązania trudnych relacji przy założeniu dobrej woli zarówno graczy z polskiej sceny politycznej jak i tych międzynarodowych. Pomimo tego, sama polityka wschodnia zaczyna jawić się Czytelnikowi jako arena skomplikowanych powiązań i międzynarodowych gier. Zmusza więc sięgającego po tę lekturę do zastanowienia i podjęcia samodzielnej refleksji, a to przecież jest najcenniejsze. 